\title{
Self-Assembling Peptide Epitopes as Novel Platform for Anticancer
} Vaccination

Rad-Malekshahi, M.; Fransen, M.F.; Krawczyk, M.; Mansourian, M.; Bourajjaj, M.; Chen, J.; ... ; Amidi, M.

\section{Citation}

Rad-Malekshahi, M., Fransen, M. F., Krawczyk, M., Mansourian, M., Bourajjaj, M., Chen, J., ... Amidi, M. (2017). Self-Assembling Peptide Epitopes as Novel Platform for Anticancer Vaccination. Molecular Pharmaceutics, 14(5), 1482-1493.

doi:10.1021/acs.molpharmaceut.6b01003

Version: $\quad$ Not Applicable (or Unknown)

License: $\quad$ Leiden University Non-exclusive license

Downloaded from: https://hdl.handle.net/1887/116020

Note: To cite this publication please use the final published version (if applicable). 


\title{
Self-Assembling Peptide Epitopes as Novel Platform for Anticancer Vaccination
}

\author{
Mazda Rad-Malekshahi, ${ }^{\dagger, \S, \|}$ Marieke F. Fransen, ${ }^{\ddagger}, \|$ Małgorzata Krawczyk, ${ }^{\dagger}$ Mercedeh Mansourian, ${ }^{\dagger}$ \\ Meriem Bourajjaj, ${ }^{\dagger}$ Jian Chen, ${ }^{\dagger}$ Ferry Ossendorp, ${ }^{\dagger}$ Wim E. Hennink, ${ }^{*}{ }^{\dagger}$ (]) Enrico Mastrobattista, ${ }^{\dagger}$ \\ and Maryam Amidi $*, \dagger$
}

${ }^{\dagger}$ Department of Pharmaceutics, Utrecht Institute for Pharmaceutical Sciences, Utrecht University, Utrecht, The Netherlands

${ }^{\ddagger}$ Department of Immunohematology and Blood Transfusion, Leiden University Medical Center, Leiden, The Netherlands

${ }^{\S}$ Department of Pharmaceutical Biomaterials and Medical Biomaterials Research Center, Faculty of Pharmacy, Tehran University of Medical Sciences, Tehran, Iran

\section{Supporting Information}

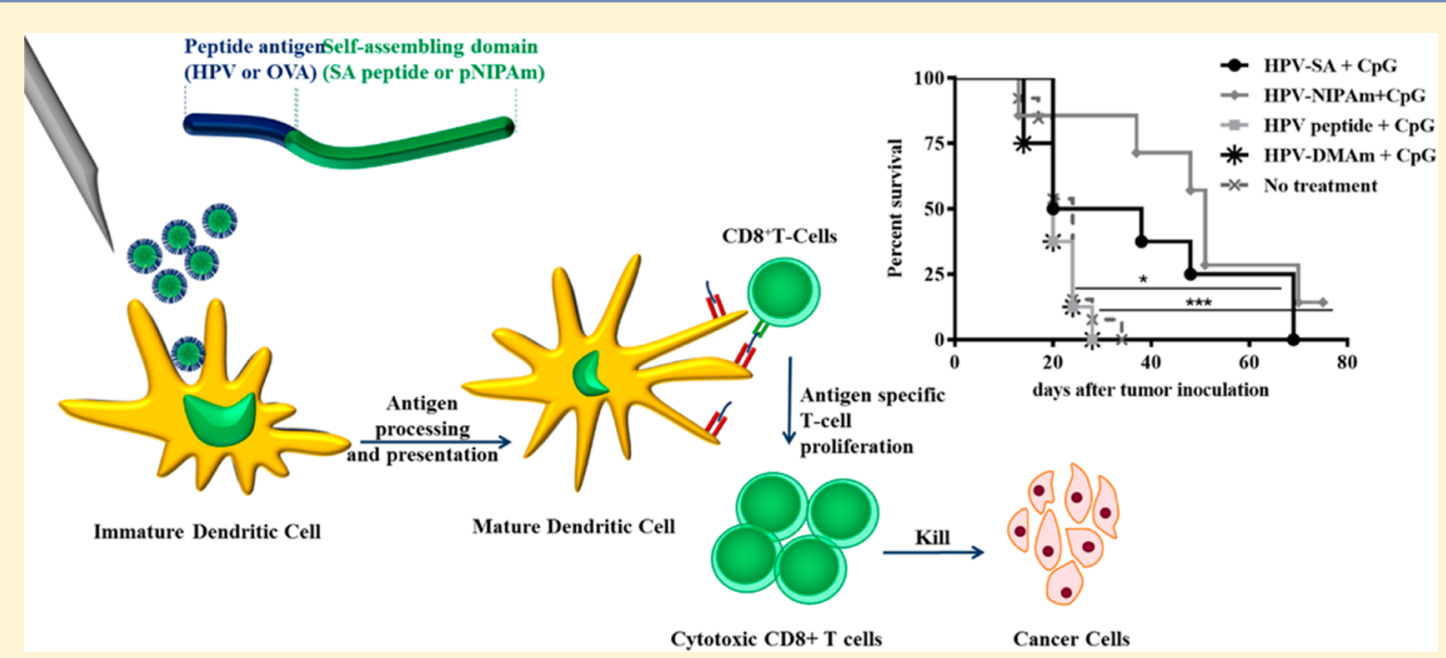

ABSTRACT: The aim of the present study was to improve the immunogenicity of peptide epitope vaccines using novel nanocarriers based on self-assembling materials. Several studies demonstrated that peptide antigens in nanoparticulate form induce stronger immune responses than their soluble forms. However, several issues such as poor loading and risk of inducing $\mathrm{T}$ cell anergy due to premature release of antigenic epitopes have challenged the clinical success of such systems. In the present study, we developed two vaccine delivery systems by appending a self-assembling peptide (Ac-AAVVLLLW-COOH) or a thermosensitive polymer poly $\left(\mathrm{N}\right.$-isopropylacrylamide $(\mathrm{pNIPAm})$ to the $\mathrm{N}$-terminus of different peptide antigens $\left(\mathrm{OVA}_{250-264}\right.$, HPV-E7 $43-57$ ) to generate self-assembling peptide epitopes (SAPEs). The obtained results showed that the SAPEs were able to form nanostructures with a diameter from 20 to $200 \mathrm{~nm}$. The SAPEs adjuvanted with CpG induced and expanded antigenspecific $\mathrm{CD}^{+} \mathrm{T}$ cells in mice. Furthermore, tumor-bearing mice vaccinated with SAPEs harboring the HPV E7 $43-57$ peptide showed a delayed tumor growth and an increased survival compared to sham-treated mice. In conclusion, self-assembling peptide based systems increase the immunogenicity of peptide epitope vaccines and therefore warrants further development toward clinical use.

KEYWORDS: therapeutic cancer vaccine, immunotherapy, human papillomavirus (HPV), ovalbumin (OVA), self-assembling peptide epitopes, nanoparticles

\section{INTRODUCTION}

Utilizing the patient's immune system represents a promising approach for eradication of cancer. ${ }^{1,2}$ The immune system is well equipped to identify and eliminate malignant cells, but cancer cells can escape from immune surveillance, which can lead to the development of tumors with the potential to metastasize. ${ }^{3,4}$ Cancer vaccines aim to evoke a strong adaptive immune response against tumor antigens, ${ }^{5-7}$ and among many different strategies applied in recent years, synthetic peptide epitopes have been an important approach for $\mathrm{T}$ cell based

Special Issue: Bioconjugate Therapeutics

Received: November 4, 2016

Revised: December 29, 2016

Accepted: January 14, 2017

Published: January 14, 2017 
Table 1. List of Peptides and Peptide-Based Self-Assembling Peptide Epitopes (SAPEs) Used in This Study

\begin{tabular}{|c|c|c|c|}
\hline name & sequence & $\begin{array}{c}M_{\mathrm{w}} \\
(\mathrm{g} / \mathrm{mol})\end{array}$ & source \\
\hline $\mathrm{OVA}_{250-264}(\mathrm{OVA})$ & NH2-SGLEQLESIINFEKL-COOH (SIINFEKL is a CTL epitope of ovalbumin) & 1719.95 & $\begin{array}{l}\text { Ansynth Service BV (Roosendaal, } \\
\text { Netherlands) }\end{array}$ \\
\hline HPV16 E7 $7_{43-57}(\mathrm{HPV})$ & $\begin{array}{l}\text { NH2-GQAEPDRAHYNIVTF-COOH (RAHYNIVTF is CTL epitope, and } \\
\text { DRAHYNI is a Th epitope of HPV E7) }\end{array}$ & 1717.86 & $\begin{array}{l}\text { Ansynth Service BV (Roosendaal, } \\
\text { Netherlands) }\end{array}$ \\
\hline $\begin{array}{l}\text { OVA-SA (contains: } \\
\text { OVA }_{250-264} \text { ) }\end{array}$ & Ac-AAVVLLLWSGLEQLESIINFEKL-COOH & 2628.11 & Genscript (New Jersey, USA) \\
\hline $\begin{array}{l}\text { HPV-SA (contains: HPV16 } \\
\text { E7 }_{43-57} \text { ) }\end{array}$ & Ac-AAVVLLLWGQAEPDRAHYNIVTF-COOH & 2626.01 & Selleck Chemicals (Houston, TX) \\
\hline
\end{tabular}

immunotherapy of cancer. ${ }^{8}$ However, unsatisfactory antitumor effects in both animal models and humans have raised the question whether these peptide epitopes, even in combination with strong adjuvants, are sufficiently immunogenic. ${ }^{9-11}$ Insufficient efficiency of minimal peptide-based vaccines may be due to their rapid extracellular degradation, fast diffusion from the site of injection and poor uptake by antigenpresenting cells, including dendritic cells (DCs), as well as lack of generation of costimulatory signals. ${ }^{12,13}$ In some publications, short peptide vaccines have been reported to induce $\mathrm{T}$-cell tolerance and anergy by direct binding to major histocompatibility complex (MHC) molecules on all cells, instead of only antigen presenting cells. ${ }^{14,15}$ Therefore, synthetic long peptides (SLPs) have been proposed as a solution of these drawbacks of the minimal peptide epitope vaccines. ${ }^{16}$ However, SLPs are still prone to enzymatic degradation by proteases present in blood and also by endopeptidases and exopeptidases present on the surface of DCs. ${ }^{16}$ Moreover, due to their relatively small size, these peptide vaccines are rapidly cleared from the injection site, and as a consequence, their uptake by DCs is limited. ${ }^{17,18}$ Furthermore, lack of information on pharmacokinetic and physical properties (solubility/aggregation) of peptide vaccines impedes control and prediction of immune responses. ${ }^{12}$ Numerous studies have demonstrated that delivery of peptide vaccines through particulate carriers (e.g., polymeric or lipidic nanostructures) can improve the efficacy of peptide epitopes through, for example, protection against degradation and better uptake by DCs. ${ }^{19-24}$

Self-assembling peptides have gained increasing attention as a way to construct biomaterials for biomedical applications such as scaffolds for tissue engineering or nanomaterials for drug and vaccine delivery. ${ }^{25}$ Self-assembling peptides can be synthesized by both standardized solid phase peptide synthesis methods and recombinant technology. ${ }^{26,27}$ Furthermore, these peptides are easy to formulate since simple dispersion in aqueous media results in the spontaneous formation of discrete and uniform particles, without the need for laborious processing as often the case for other particulate systems. ${ }^{28,29}$ Furthermore, other functionalities such as adjuvanticity and receptor/cell specificity can be introduced in a single polypeptide. ${ }^{25}$ In the present study, we have designed short amphiphilic peptides (SA2 and SA7: Ac-AAVVLLLWE $2-7-\mathrm{COOH}$ ) that form nanovesicular structures in aqueous solution. ${ }^{30}$ The self-assembly was due to both hydrophobic clustering and intermolecular hydrogen bond formation as driving forces. ${ }^{26,28}$

Progress in polymer science has resulted in a variety of polymers suitable for drug delivery applications. ${ }^{31}$ Particularly, stimuli-responsive polymers that respond to certain stimuli such as $\mathrm{pH}$, temperature, light, magnetism, or ultrasound have received tremendous interest in the last decades. ${ }^{32}$ As an example, poly( $N$-isopropylacrylamide) (pNIPAm), is hydrophilic and water-soluble below the so-called lower critical solution temperature (LCST), whereas above this temperature of $\sim 33{ }^{\circ} \mathrm{C}$ it is insoluble in water and precipitates. Because of this thermoreversible behavior pNIPAm has been used in triggerable drug delivery systems. ${ }^{34,33}$

The aim of this study was to augment the immunogenicity of peptide epitopes by conjugating them to self-assembling moieties to obtain well-defined nanostructures for cancer immunotherapy. In the present study, the $\mathrm{OVA}_{250-264}$ peptide (SGLEQLESIINFEKL (covering a $\mathrm{CD}^{+}$epitope of ovalbumin: SIINFEKL)) and the HPV16 E7 ${ }_{43-57}$ of the E7 protein of human papillomavirus type 16 (GQAEPDRAHYNIVTF (covering both a $\mathrm{CD}^{+}$epitope RAHYNIVTF and a CD4+ epitope PDRAHYNI)) were conjugated to the hydrophobic domain of the SA2 peptide (Ac-AAVVLLLW-COOH) or to the thermosensitive polymer (pNIPAm) to trigger peptide selfassembly into discrete nanostructures. The peptide vaccines were biophysically characterized, and their capacity to induce or expand antigen-specific $\mathrm{CD}^{+} \mathrm{T}$ cell were tested in mice. Finally, in vivo studies in mice were conducted to evaluate the efficacy of SAPEs that contain the HPV peptide epitope (HPV SAPEs) as a therapeutic vaccine.

\section{EXPERIMENTAL SECTION}

2.1. Materials. Acetonitrile (ACN), dichloromethane (DCM), dimethylformamide (DMF), methyl-tert-butyl ether (MTBE), N-methyl-2-pyrrolidine (NMP), $n$-hexane, and diethyl ether were purchased from Biosolve BV (Valkenswaard, The Netherlands). N-Isopropylacrylamide (NIPAm; >99\%), $N, N$-dimethyl acrylamide (DMAm; >99\%), deuterium oxide $\left(\mathrm{D}_{2} \mathrm{O}\right)$, deuterated dimethyl sulfoxide, (99.9\%, DMSO- $\left.d_{6}\right), \alpha$ bromoisobutyryl bromide, triisopropylsilan, Nile red, poly-Llysine, hexafluoroisopropanol (HFIP), and 4-(2-hydroxyethyl) piperazine-1-ethanesulfonic acid (HEPES) were purchased from Sigma-Aldrich (Zwijndrecht, The Netherlands). Sodium hydroxide and HCL were bought from Merck (Darmstadt, Germany). N,N-Diisopropyl-ethylamine (DIPEA) was purchased from Biosolve (Valkenswaard, The Netherlands). $\mathrm{CuCl}$ and $\mathrm{CuCl}_{2}$ were obtained from Sigma-Aldrich (Zwijndrecht, The Netherlands). Phosphate-buffered saline ( $\mathrm{NaCl}, 8.2$ $\left.\mathrm{g} / \mathrm{L} ; \mathrm{Na}_{2} \mathrm{HPO}_{4} \cdot 12 \mathrm{H}_{2} \mathrm{O}, 3.1 \mathrm{~g} / \mathrm{L} ; \mathrm{NaH}_{2} \mathrm{PO}_{4} \cdot 2 \mathrm{H}_{2} \mathrm{O}, 0.3 \mathrm{~g} / \mathrm{L}\right)$ (PBS) was purchased from B. Braun (Melsungen, Germany). Iscove's Modified Dulbecco's Medium (IMDM) was purchased from Lonza (Walkersville, USA). CPG ODN 1826 (CpG) was purchased from InvivoGen (Cayla, France). Tris(2dimethylaminoethyl)amine ( $\left.\mathrm{Me}_{6} \mathrm{TREN}\right)$ was prepared according to a reported procedure. ${ }^{34}$ PE-labeled $\mathrm{H}-2 \mathrm{D}^{\mathrm{b}}$ epitope E7 $49-57$ (RAHYNIVTF)- and PE-labeled $\mathrm{H}_{-2} \mathrm{D}^{\mathrm{b}}$ epitope OVA $_{257-264}$ (SIINFEKL)-containing tetramers were constructed and used for the analysis of peptide-specific CTL 
immunity as described earlier. ${ }^{35}$ All other chemicals were of analytical grade, and all aqueous solutions were prepared with Millipore Milli-Q deionized water (18.2 M 2 ; Millipore Milli-Q system, Billerica, MA). HEPA vent filters were obtained from Whatman (Kent, U.K.).

Resin-protected peptide epitopes of ovalbumin $\left(\mathrm{OVA}_{250-264}\right.$ : DEVSGLEQLESIINFEKL) and human papilloma virus type 16 (HPV 16) oncoprotein E7 (HPV16-E7 43-57: GQAEPDRAHYNIVTF) were ordered from Ansynth Service BV (Roosendaal, Netherlands). The purity of the mentioned peptides as determined by reverse-phase HPLC and mass spectrometry was $>90 \%$. The characteristics of the other peptides that were used in this study are listed in Table 1 . The peptides were synthesized by standard solid-phase peptide synthesis and delivered with a purity $>95 \%$.

2.2. Synthesis of Peptide-Polymer Conjugates. 2.2.1. Synthesis of OVA and HPV Peptide-ATRP Macroinitiator. The synthesis of the OVA and HPV peptide-ATRP macroinitiator is shown in Scheme 1. Resin-protected peptides

Scheme 1. Synthesis of ATRP Peptide Macroinitiator

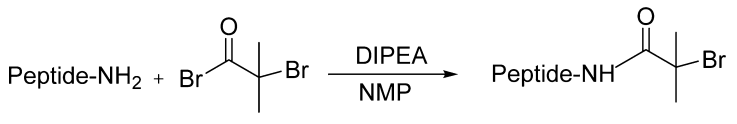

$\left(\mathrm{OVA}_{250-264}\right.$ or HPV16 E7 $\left.43-57\right)$ with deprotected $\mathrm{N}$-terminus (equal to $0.1 \mathrm{mmol}$ of the peptide) was dispersed in and washed three times with $5 \mathrm{~mL}$ of dried dichloromethane. Next, the resin was washed three times with $5 \mathrm{~mL}$ of NMP. Subsequently, 3 equiv of DIPEA and 2 equiv of 2-bromoisobutyryl bromide (relative to $-\mathrm{NH}_{2}$ groups) in NMP were added. The reaction mixture was stirred for $16 \mathrm{~h}$ at room temperature. The Kaiser test ${ }^{36}$ was done to determine nonreacted free amines, and when this test was negative, the reaction was considered completed. The peptide-initiator was deprotected and cleaved from the resin as follows. First, the resin washed three times with NMP and subsequently a solution of TFA/water/triisopropylsilan (95/2.5/2.5 v/v/v \%) was added and incubated for $4 \mathrm{~h}$ at room temperature under vigorous shaking to fully deprotect the peptide. Next, the peptide-initiator product was precipitated in a cold MTBE $/ n$ hexane $(1 / 1 ; \mathrm{v} / \mathrm{v} \%)$, separated, and washed two times with $\mathrm{MTBE} / n$-hexane using centrifugation $\left(3000 \times g, 5 \mathrm{~min}, 4^{\circ} \mathrm{C}\right)$. The obtained product was dispersed in water and freeze-dried using a Christ "Alpha 1-2" freeze-dryer (Osterode, Germany). The molecular masses of the synthesized peptide-initiator was determined by electrospray mass spectrometry.
2.2.2. Synthesis of OVA- and HPV-poly(NIPAm) and HPVpoly(DMAm) Conjugates. The $\mathrm{OVA}_{250-264^{-}}$and the HPV16 E7 $43-57$-poly(NIPAm) peptide-polymer conjugates, referred to as OVA-pNIPAm and HPV-pNIPAm, and HPV16 E7 ${ }_{43-57^{-}}$ poly(DMAm), referred as to HPV-pDMAm, were synthesized using atom transfer radical polymerization (ATRP). ${ }^{37}$ The polymerization reaction is shown in Scheme 2.

The peptide macroinitiator $(20 \mu \mathrm{mol})$ was dissolved in $2 \mathrm{~mL}$ of water/ACN $(80: 20 \mathrm{v} / \mathrm{v} \%)$ in a screw-capped septum vial. In case of $\mathrm{OVA}_{250-264}$, the peptide was first dissolved in an alkaline solution ( $\mathrm{pH} 12)$, and subsequently, the $\mathrm{pH}$ was adjusted to $\mathrm{pH}$ 8.5 with $\mathrm{HCl}(0.5 \mathrm{M})$. In another screw-capped septum vial, 15 $\mu \mathrm{mol}$ of $\mathrm{CuBr}, 0.05 \mu \mathrm{mol}$ of $\mathrm{CuBr}_{2}$, and $5.3 \mathrm{mmol}(600 \mathrm{mg})$ of NIPAm or $525 \mathrm{mg}$ of DMAm were dissolved in $3 \mathrm{~mL}$ of water/ ACN $(80: 20 \mathrm{v} / \mathrm{v} \%)$. The vials were capped with a septum and the solutions were flushed with $\mathrm{N}_{2}$. Next, the peptide solution was added to the NIPAm or DMAm solution, flushed with $\mathrm{N}_{2}$, and placed in an ice bath, under rapid stirring. The polymerization was initiated by adding $0.1 \mathrm{~mL}$ of $0.4 \mathrm{M}$ $\mathrm{Me}_{6}$ TREN solution in water (degassed by flushing with $\mathrm{N}_{2}$ prior to addition), which immediately turned the reaction mixture blue. Periodically, $50 \mu \mathrm{L}$ samples were taken, diluted in air-saturated $\mathrm{D}_{2} \mathrm{O}$, and analyzed by ${ }^{1} \mathrm{H}$ NMR to determine the NIPAm or DMAm conversion. ${ }^{37}$ When the conversion was $\sim 70 \%$, the reaction was stopped by flushing air into the reaction mixture. The crude product was dialyzed (with dialysis cassettes of $3000 \mathrm{kDa} \mathrm{MWCO}$ ) against water at $4{ }^{\circ} \mathrm{C}$ for 2 days and subsequently lyophilized. The peptide-polymer conjugates were characterized by gel permeation chromatography (GPC) using Mixed-D columns (Polymer Laboratories), a solution of $10 \mathrm{mM} \mathrm{LiCl}$ in DMF as eluent, a flow of $0.7 \mathrm{~mL} / \mathrm{min}$, and a temperature of $40{ }^{\circ} \mathrm{C}$. A refractive index detector was used, and PEG standards were used for calibration.

2.2.3. Formulation Preparation of Self-Assembling Peptide-Epitope (SAPE) Vaccines. 2.2.3.1. Peptide-Peptide Vaccines. All peptide formulations indicated in Table 1 (except OVA-SA peptide) were prepared as follows. One milligram of the peptide was hydrated with $40 \mu \mathrm{L}$ of $0.2 \mathrm{M} \mathrm{NaOH}$ solution, and subsequently, phosphate buffered saline (PBS, $140 \mathrm{mM}$ $\mathrm{NaCl}, 13 \mathrm{mM} \mathrm{Na}_{2} \mathrm{HPO}_{4}$, and $2.5 \mathrm{mM} \mathrm{NaH}_{2} \mathrm{PO}_{4}, \mathrm{pH}$ 7.4) was added in $200 \mu \mathrm{L}$ portions up to $1 \mathrm{~mL}$. After each step, the peptide dispersion was sonicated in a water bath sonicator (Fisher Scientific, Loughborough, UK) for $3 \mathrm{~min}$ at $30{ }^{\circ} \mathrm{C}$. Before reaching to final volume, the $\mathrm{pH}$ was adjusted to $\mathrm{pH} 7.4$ by dropwise adding $0.2 \mathrm{M} \mathrm{HCl}$. To prepare the OVA-SA peptide formulation, one milligram of this peptide was dissolved in $200 \mu \mathrm{L}$ of HFIP. After solvent evaporation, the obtained peptide film was hydrated in $40 \mu \mathrm{L}$ of $0.2 \mathrm{M} \mathrm{NaOH}$,

Scheme 2. Polymerization Reaction of (a) NIPAm and (b) DMAm Using the Peptide Macroinitiator

a)<smiles>C=CC(=O)NC(C)C</smiles>

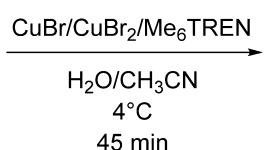

$45 \mathrm{~min}$

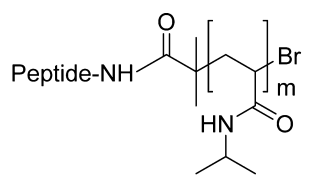

Peptide-pNIPAm

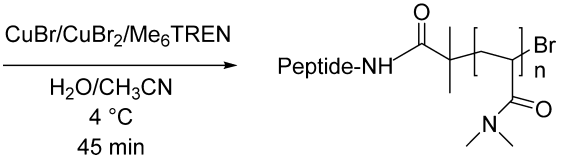


Table 2. List of Vaccine Formulations Used for Immunization Studies

\begin{tabular}{|c|c|c|c|c|c|c|c|c|}
\hline \multirow{2}{*}{\multicolumn{2}{|c|}{ in vivo experiment }} & \multicolumn{7}{|c|}{ groups } \\
\hline & & 1 & 2 & 3 & 4 & 5 & 6 & 7 \\
\hline \multirow[t]{3}{*}{ OVA $^{a}$} & antigen cross presentation & $\begin{array}{l}\text { OVA-SA } \\
\quad+\mathrm{CpG}^{c}\end{array}$ & $\begin{array}{l}\text { OVA- } \\
\text { pNIPAm + } \\
\text { CpG }\end{array}$ & $\begin{array}{l}\text { OVA peptide } \\
\quad+\mathrm{CpG}\end{array}$ & $\begin{array}{l}\text { no } \\
\text { treatment }\end{array}$ & & & \\
\hline & $\begin{array}{l}\text { vaccination in naïe mice Induction of } \\
\text { endogenous } \mathrm{CD}^{+} \mathrm{T} \text { cells }\end{array}$ & $\begin{array}{l}\text { HPV- } \\
\text { pNIPAm + } \\
\text { CpG }\end{array}$ & $\begin{array}{l}\text { HPV- } \\
\text { pNIPAm }\end{array}$ & $\begin{array}{l}\text { HPV peptide } \\
\quad+\mathrm{CpG}\end{array}$ & $\begin{array}{l}\text { HPV } \\
\text { peptide }\end{array}$ & no treatment & & \\
\hline & & $\begin{array}{l}\mathrm{HPV}-\mathrm{SA} \\
\mathrm{CPG}\end{array}$ & no treatment & & & & & \\
\hline $\mathrm{HPV}^{b}$ & therapeutic tumor experiment & $\underset{\mathrm{CpG}}{\mathrm{HPV}-\mathrm{SA}+}$ & HPV-SA & $\begin{array}{l}\text { HPV- } \\
\text { pNIPAm + } \\
\text { CpG }\end{array}$ & $\begin{array}{l}\text { HPV- } \\
\text { pNIPAm }\end{array}$ & $\begin{array}{l}\text { HPV- } \\
\text { pDMAm + } \\
\text { CpG }\end{array}$ & $\begin{array}{l}\text { HPV peptide } \\
\quad+\mathrm{CpG}\end{array}$ & $\begin{array}{l}\text { no } \\
\text { treatment }\end{array}$ \\
\hline
\end{tabular}

${ }^{a_{1}}$ The dose of antigen in OVA-SA, OVA-pNIPAm, and OVA peptide was $40 \mathrm{nmol} /$ injection (concentration: $\left.200 \mu \mathrm{M}\right) .{ }^{{ }^{b}}$ The dose of antigen in HPVSA, HPV-pNIPAm, HPV-pDMAm, and HPV peptide was $60 \mathrm{nmol} /$ injection (concentration: $300 \mu \mathrm{M}){ }^{c}{ }^{c}$ The dose of CPG in the formulations was $20 \mu \mathrm{g} /$ injection.

and then similar to other peptide preparations, $1 \mathrm{~mL}$ of $\mathrm{PBS}$ ( $140 \mathrm{mM} \mathrm{NaCl}, 13 \mathrm{mM} \mathrm{Na}_{2} \mathrm{HPO}_{4}$, and $2.5 \mathrm{mM} \mathrm{NaH}_{2} \mathrm{PO}_{4}, \mathrm{pH}$ 7.4) was added in $200 \mu \mathrm{L}$ portions. After $\mathrm{pH}$ adjustment, some of the peptide formulations were supplemented with CpG (20 $\mu \mathrm{g}$ per injection; $10 \mu \mathrm{L}$ of a $2 \mathrm{mg} / \mathrm{mL}$ of a stock solution of $\mathrm{CpG}$ in PBS) as an adjuvant (Table 2).

2.2.3.2. Peptide-Polymer Vaccines. Peptide-pNIPAm formulations were prepared by either a rapid heating ${ }^{38}$ or a heat shock $^{39}$ procedure. First, the thermosensitive peptidepNIPAm conjugates and nonthermosensitive peptidepDMAm, as a nonself-assembling peptide-polymer conjugate, were dissolved in $10 \mathrm{mM}$ PBS or $20 \mathrm{mM}$ HEPES at room temperature. Subsequently, some of the formulations were supplemented with CpG (20 $\mu \mathrm{g}$ per injection; $10 \mu \mathrm{L}$ of $2 \mathrm{mg} /$ $\mathrm{mL}$ stock solution of $\mathrm{CpG}$ in PBS), as an adjuvant (Table 2). For the heat shock procedure, $100 \mu \mathrm{L}$ of polymer solution (1 $\mathrm{mg} / \mathrm{mL}$ ) with or without $\mathrm{CpG}$ was added to $900 \mu \mathrm{L}$ of PBS or HEPES heated at $50{ }^{\circ} \mathrm{C}$. Next, the self-assembled nanostructures were equilibrated at $37{ }^{\circ} \mathrm{C}$ for at least 5 min before being analyzed for their physicochemical properties. For the rapid heating procedure, an aqueous polymer solution $(1-10 \mathrm{mg} / \mathrm{mL}$ in PBS or HEPES) was rapidly heated at $50{ }^{\circ} \mathrm{C}$ and kept at this temperature for $5 \mathrm{~min}$. Subsequently, the formed nanoassemblies were cooled down to $37^{\circ} \mathrm{C}$ until further analysis.

2.2.4. Characterization of SAPEs. 2.2.4.1. Critical Aggregation Concentration Determination. The critical aggregation concentration (CAC) of the OVA-SA and HPV-SA vaccines was determined using the Nile red assay as described by Zhang et al. $^{40}$ In short, peptide-based SAPEs were dissolved in PBS $(\mathrm{pH} 7.4)$ in concentrations ranging from 0.1 to $500 \mu \mathrm{g} / \mathrm{mL}$. Next, $200 \mu \mathrm{L}$ of each dilution was spiked with $0.2 \mu \mathrm{L}$ of Nile red solution (1.25 mM in ethanol). After overnight incubation at room temperature, fluorescence emission (Ex550/Em635) was measured by a Horiba fluorolog fluorometer (Horiba Jobin Yvon, Longjumeau Cedex, France). The fluorescence intensity at $635 \mathrm{~nm}$ was plotted against the logarithm of peptide concentrations to determine the CAC. The point of intersection of two linear fits of the plot was considered as the CAC value. The CAC of OVA-pNIPAm and HPVpNIPAm vaccines was determined by dynamic light scattering (DLS, Malvern Instruments, Malvern, U.K.). In detail, peptidepNIPAm conjugates were dissolved in PBS ( $\mathrm{pH}$ 7.4) in concentrations ranging from 1 to $1000 \mu \mathrm{g} / \mathrm{mL}$. The thermosensitive SPAEs (peptide-pNIPAm) were formed by the rapid heating method, as described above. The $Z$-average diameter $\left(Z_{\text {ave }}, \mathrm{nm}\right)$ and light scattering intensity (LSI) of the
SAPE dispersion were monitored by DLS at $37^{\circ} \mathrm{C}$. The LSI was plotted against the logarithm of the conjugate concentrations, and the point of intersection of two linear fits of the plot was considered as the CAC of the peptide-pNIPAm SAPEs.

2.2.4.2. Particle Size and Zeta Potential Measurement. The prepared SAPE particles in PBS ( $\mathrm{pH}$ 7.4) were sized using an ALV CGS-3 goniometer system (Malvern Instruments, Malvern, U.K.) equipped with a JDS Uniphase $22 \mathrm{~mW} \mathrm{He}-\mathrm{Ne}$ laser operating at $632.8 \mathrm{~nm}$, an optical fiber-based detector, a digital LV/LSE-5003 correlator. and a temperature controller (Julabo water bath). The DLS time correlation was analyzed by ALV Correlator 3.0 software (ALV, Langen, Germany). Zeta potential measurement of the peptide particles was performed in $10 \mathrm{mM}$ HEPES, $\mathrm{pH} 7.0$, at $25{ }^{\circ} \mathrm{C}$ for the peptide-peptide and $37{ }^{\circ} \mathrm{C}$ for the peptide-pNIPAm assemblies using a Malvern Zetasizer Nano-Z (Malvern Instruments, Malvern, U.K.) with universal ZEN 1002 "dip" cells and DTS (Nano) software (version 4.20). DTS 1235 latex beads (Zeta Potential Transfer Standard, Malvern Instruments, Malvern, U.K.) were used for calibration.

2.2.4.3. Particle Morphology. The morphology and size of the peptide-pNIPAm SAPEs were visualized by transmission electron microscopy (TEM). Briefly, samples $(0.1 \mathrm{mg} / \mathrm{mL}$ in HEPES $10 \mathrm{mM}$ ) were soaked onto prewarmed carbon-coated copper grids for $2 \mathrm{~min}$, and excess liquid was removed by a filter paper. The grids were subjected to negative staining with $2 \%$ uranyl acetate (Merck, Germany) for $45 \mathrm{~s}$ and dried for 10 $\mathrm{min}$ at room temperature before acquisition of TEM images (Tecnai 10, Philips, The Netherlands). Atomic force microscopy (AFM) was applied to visualize the morphology of the peptide-based vaccines. Briefly, $40 \mu \mathrm{L}$ of a $0.02 \%(\mathrm{w} / \mathrm{v})$ polylysine solution in water was placed on a freshly cleaved mica substrate and, after 5 min incubation, washed with filtered Milli-Q water followed by drying under $\mathrm{N}_{2}$ flow. Next, $30 \mu \mathrm{L}$ of the sample was loaded on the treated mica and incubated for 1 min, followed by washing three times with $20 \mu \mathrm{L}$ of filtrated Milli-Q water to discharge nonattached particles and salts. Finally, the prepared sample was dried by an $\mathrm{N}_{2}$ flow. ScanAsyst image mode was used at room temperature with a Digital Instruments NanoScope $\mathrm{V}$, equipped with silicon nitride cantilevers (Veeco, NY, USA). Images were analyzed by NanoScope Analysis 1.40 software. Several images were taken at different days of individually prepared samples.

2.2.4.4. Circular Dichroism. Circular dichroism spectra were obtained by a double beam DSM 1000 CD spectrometer 
(Online Instrument Systems, Bogart, GA, USA) using quartz cuvettes with different path length appropriate for the different concentrations. Samples of peptide-based SAPEs (at concentration of $200 \mathrm{mM}$ OVA-SA and $300 \mathrm{mM}$ HPV-SA) were prepared in PBS ( $\mathrm{pH} 7.4,140 \mathrm{mM} \mathrm{NaCl}$ ). Five measurements at $25{ }^{\circ} \mathrm{C}$ using $1 \mathrm{~nm}$ intervals and $1 \mathrm{~nm}$ bandwidth at a wavelength range from $185-250 \mathrm{~nm}$ were performed. Next, the spectrum of the buffer was subtracted from the averaged spectrum of the samples. To normalize for concentration, the results are presented as molar ellipticity.

2.2.5. Cell Lines. TC-1 cells were derived from primary lung epithelial cells of C57BL/6 mice cotransformed with HPV-16 E6 and E7 and c-Ha-ras oncogenes. ${ }^{41}$ These cells were cultured at $37{ }^{\circ} \mathrm{C}$ with $5 \% \mathrm{CO}_{2}$ in IMDM, supplemented with $8 \%$ fetal calf serum (FCS) (Greiner), $400 \mu \mathrm{g} / \mathrm{mL}$ of Geneticin (G418) (Life Technology), $2 \mathrm{mM}$ L-glutamine, $1 \mathrm{mM}$ sodium pyruvate, $2 \mathrm{mM}$ nonessential amino acid, and $100 \mathrm{IU} / \mathrm{mL}$ penicillin. ${ }^{42}$

2.2.6. In Vivo MHC Class I-Restricted Antigen Presentation with OVA SAPEs. To establish antigen presentation in vivo, $\mathrm{CD}^{+} \mathrm{T}$ cells were isolated from spleen and lymph nodes of CD90.1 OT-I mice. T cells were enriched using the CD8+ enrichment kit according to manufacturer's protocol (BD Bioscience), and 500,000 cells were injected intravenously into the tail vein of CD90.2 mice ( $n=5$ /group). One day later, mice were vaccinated via subcutaneous (s.c.) injection with selfassembled or soluble peptide constructs containing OVA CTL epitopes (40 nmol/injection) (Table 2). Peripheral blood mononuclear cells (PBMCs) were collected at days 3, 5, 7, and 10 after immunization to analyze the expansion of the transferred OVA-specific $T$ cells caused by cross presentation of the OVA antigen. After lysis of red blood cells, T cells were stained with fluorescently labeled antibodies for $\operatorname{CD} 8 \alpha$ and the OT-I congenic marker CD90.1 (Thy1.1) and analyzed by flow cytometry. $\mathrm{T}$ cell expansion is expressed as the number of transferred (OT-I) T cells as a percentage of total $\mathrm{CD} 8^{+} \mathrm{T}$ cells.

2.2.7. Endogenous $C D 8^{+} T$ Cell Activation. To evaluate the potency of the SAPE vaccines to induce endogenous specific $\mathrm{CD} 8^{+} \mathrm{T}$ cells, naïve $\mathrm{C} 57 \mathrm{BL} / 6$ mice $(n=5)$ were s.c. vaccinated in the right flank with the indicated formulations in Table 2. After 14 days, the mice received a booster injection. PBMCs were collected 10 days after prime vaccination and 5 and 7 days after the boost vaccination. To quantify antigen-specific $\mathrm{CD} 8^{+}$ $\mathrm{T}$ cells by flow cytometry, after lysis of red blood cells, $\mathrm{T}$ cells were stained with $\mathrm{CD} 8 \alpha$ and $\mathrm{H}-2 \mathrm{Db}$ E7 ${ }_{49-57} \mathrm{APC}$ tetramer for $\mathrm{HPV}$ vaccines.

2.2.8. Therapeutic Vaccination in Mice with Established Tumor. Groups of mice $(n=12)$ were challenged in the right flank with 100,000 TC-1 tumor cells. At day 7, when the tumors were palpable (tumor size between 0.5 and $10 \mathrm{~mm}^{3}$ ), mice were s.c. vaccinated with the vaccine formulations (Table 2). Mice received a booster immunization 14 days after prime vaccination. Tumor size was measured two-dimensionally with calipers 2-3 times per week and followed for approximately 35 days. $^{43}$

Mice were sacrificed for ethical reasons when the actual tumor volume reached about $2000 \mathrm{~mm}^{3}$ or when the tumor became ulcerated. Before and after booster vaccination, blood samples were collected via tail vein in heparinized tubes for detecting HPV-specific $\mathrm{CD}^{+} \mathrm{T}$ by flow cytometry.

2.2.9. Statistical Analysis. Data were analyzed using GraphPad Prism 5.02 software. For tumor experiments, Kaplan-Meier survival curves were applied, and the differences between survival curves were analyzed by log-rank test $(p<$
0.05 was considered statistically significant). Expansion of antigen-specific $\mathrm{CD}^{+} \mathrm{T}$ cells in the blood of immunized mice after booster vaccination with the SAPE vaccines was compared to control mice by student $t$ test. The percentage of OT-I cells on day 5 postimmunization in mice treated with SAPE vaccines was compared to control group by student $t$ test.

\section{RESULTS AND DISCUSSION}

3.1. Design of Peptide-Based SAPEs. The SA2 peptide was previously designed and studied in depth as a selfassembling peptide forming nanovesicles in aqueous solutions. ${ }^{29}$ In the present study, we have exploited the capacity of SA2 hydrophobic domain (SA: Ac-AAVVLLLW-COOH) to form nanostructures once conjugated to antigen epitopes. To this end, peptides $\left(\mathrm{OVA}_{250-264}\right.$ (SGLEQLESIINFEKL) derived from chicken ovalbumin and containing the $\mathrm{H} 2 \mathrm{~b}$ restricted MHC class I peptide epitope SIINFEKL, and HPV7 $7_{43-57}$ (GQAEPDRAHYNIVTF) derived from human papillomavirus $\mathrm{E} 7$ protein and containing the $\mathrm{H} 2 \mathrm{~b}$ restricted MHC class I peptide epitope RAHYNIVTF) were fused to the C-terminus of the SA domain (OVA-SA and HPV-SA, Table 1). In the selected $\mathrm{HPV7}_{43-57}$ and $\mathrm{OVA}_{250-264}$ peptides, the presence of the natural flanking amino acids, GQAEPD at the N-terminus of the HPV and SGLEQLE at the N-terminus of OVA CTL epitopes, allows proper cleavage and processing of the peptides in DCs. ${ }^{44,45}$

3.2. Synthesis and Characterization of PeptidepNIPAm and -pDMAm Conjugates. The OVA and HPV peptide macroinitiators were synthesized by coupling an ATRP initiator to the $\mathrm{N}$-terminus of the peptides (Scheme 1). The molecular masses of the peptide-initiators were determined using an electron spray mass spectrometer, and this analysis showed that the ATRP initiator was coupled to the N-terminus of the peptides (data not shown). OVA-pNIPAm, HPVpNIPAm, and HPV-pDMAm peptide-polymer conjugates were synthesized by ATRP using NIPAm and DMAm, as the monomer and the peptide macroinitiators (Scheme 2). The structures of the synthesized polymers were confirmed by ${ }^{1} \mathrm{H}$ NMR spectroscopy. Table 3 summarizes the molecular

Table 3. Characteristics of Peptide-pNIPAm Conjugates Used in This Study

$\begin{array}{cccc}\text { Peptide-pNIPAm } & M_{\mathrm{n}}{ }^{a} & M_{\mathrm{w}}{ }^{a} & M_{\mathrm{w}} / M_{\mathrm{n}} \\ \text { OVA-pNIPAm } & 28,400 & 33,600 & 1.18 \\ \text { HPV-pNIPAm } & 38,900 & 42,100 & 1.08 \\ \text { HPV-pDMAm } & 29,500 & 35,100 & 1.19 \\ M_{\mathrm{n}}=\text { number-average molar weight }(\mathrm{g} / \mathrm{mol}) \text { and } M_{\mathrm{w}}=\text { weight- } \\ \text { verage molar weight }(\mathrm{g} / \mathrm{mol}) \text { as determined by GPC. }\end{array}$

characteristics of the synthesized polymers. The resulting OVA-pNIPAm and HPV-pNIPAm peptide-polymer conjugates have pNIPAm block length of $M_{\mathrm{n}} \approx 30,000$ and $40000 \mathrm{~g} /$ mol and a fixed peptide molecular weight of $1719 \mathrm{~g} / \mathrm{mol}$ (OVA) and $1717 \mathrm{~g} / \mathrm{mol}$ (HPV), respectively. The HPVpDMAm peptide polymer conjugate had also $M_{\mathrm{n}} \approx 30000 \mathrm{~g} /$ mol, similar to the peptide-pNIPAm conjugates. ATRP was used for the synthesis of the peptide-pDMAm and peptidepNIPAm conjugates since this is an efficient polymerization technique, especially for acrylamides, and results in polymers with a very low polydispersity. ${ }^{46,47}$ The synthesized peptidepNIPAm and peptide-pDMAm conjugates had an average molecular weight close to the target value and a very low 
polydispersity. It has been shown that pNIPAm is a thermosensitive polymer with an LCST around $33{ }^{\circ} \mathrm{C}$ in aqueous solution. ${ }^{48}$ Consequently, it is expected that peptidepNIPAm conjugate can form self-assemblies with a hydrophilic peptide shell and a hydrophobic pNIPAm core above the LCST of the pNIPAm blocks as first described for PEG-pNIPAm. ${ }^{49}$ However, pDMAm is a nonthermosensitive/fully water-soluble polymer, and the resulting peptide-pDMAm conjugate does, therefore, not self-assemble into nanoparticles and was used as a control formulation in the in vivo tumor experiments.

3.3. Characterization of Self-Assembling Peptide Epitopes (SAPEs). To characterize the peptide nanostructures, several complementary methods were applied (Table 4). In

Table 4. Characteristics of the Self-Assembling Peptides Epitopes Used in the Present Study

\begin{tabular}{ccc}
\multicolumn{1}{c}{ peptide(s) } & $\begin{array}{c}\text { size }(\mathrm{nm})^{a, b} \\
/ \text { PDI }\end{array}$ & $\begin{array}{c}\text { zeta potential }^{b} \\
(\mathrm{mV})\end{array}$ \\
OVA-SA (Ac- & $24 \pm 3$ & $-17 \pm 1$ \\
AAVVLLLWSGLEQLESIINFEKL) & $/ 0.29 \pm 0.16$ & \\
HPV-SA (Ac- & $86 \pm 7$ & $-20 \pm 2$ \\
AAVVLLLWGQAEPDRAHYNIVTF) & $/ 0.37 \pm 0.03$ & \\
OVA-pNIPAm & $115 \pm 3$ & $-19 \pm 1$ \\
& $/ 0.10 \pm 0.02$ & \\
HPV-pNIPAm & $196 \pm 2$ & $-16 \pm 2$ \\
& $/ 0.07 \pm 0.03$ &
\end{tabular}

${ }^{a}$ Measurement was performed by dynamic light scattering. ${ }^{b}$ All measurements were repeated three times.

peptide based systems, similar to the previously reported SA2 peptide, amphiphilic peptide epitopes self-assembled into discrete nanostructures above a threshold concentration, the critical aggregation concentration (CAC). The CAC values of the OVA-SA and HPV-SA vaccines were both ca. $15 \mu \mathrm{M}$, which is in the same range as that of SA2, ${ }^{29}$ and indicate that the peptide epitope sequences appended to the C-terminus of the self-assembling SA domain had marginal influence on the CAC. $^{29}$

AFM revealed that OVA-SA particles had a spherical morphology with similar particle size as measured by DLS (Figure 1). The obtained HPV-SA nanoparticles were also analyzed at concentrations used for the in vivo experiments (300 $\mu \mathrm{M})$, which showed consistent characteristics regarding size and morphology. DLS for the HPV-SA peptide revealed that self-assembling peptide formed nanostructures with a mean hydrodynamic diameter of $85 \mathrm{~nm}$ and a PDI of 0.4 (Table 4). AFM analysis of the immobilized nanostructures on mica revealed toroidal structures with a diameter of $\sim 100 \mathrm{~nm}$ in accordance with the size obtained by DLS (Figure 1). The observed concave structures may suggest a hollow, vesicular nature of these nanostructures, similar to the vesicular structures formed by the previously reported SA2 peptide. $^{30}$ Although the CAC for the different SA based peptides were dictated by the SA tag, the morphology of the nanoparticles, however, was affected by the appended peptide epitope sequences. Negative zeta potential was seen for both SAPEs at $\mathrm{pH}$ 7.4. The isoelectric point ( $\mathrm{pI}$ ) of the OVA and HPV peptides are 4.1 and 5.7, respectively, ${ }^{50}$ and therefore, they bear negative charge at $\mathrm{pH} 7.4$.

The previous study on SA2 peptide demonstrated the ability of this peptide to form a stable beta-sheet structure once integrated into self-assemblies. ${ }^{29}$ However, comparison between the secondary structures of HPV-SA and OVA-SA with
SA2 above their CACs can be indicative in similarity or dissimilarity of self-assembling pathways in these series of peptides. The CD spectrum of the HPV-SA and OVA-SA nanostructures showed a negative peak between 210 and 220 $\mathrm{nm}$ (Figure S1) that is typical for peptides forming $\beta$-sheets. ${ }^{51}$ This result is in accordance with the obtained secondary structure of previously studied SA2 peptide. $^{29}$

Peptide-pNIPAm (OVA and HPV) SAPEs prepared by rapid heating in PBS were characterized for their morphology, size, polydispersity, and zeta potential (Table 4). OVA-pNIPAm and HPV-pNIPAm SAPEs had a mean hydrodynamic diameter of 115 and $196 \mathrm{~nm}$, respectively, with a narrow size distribution (Table 4). TEM analysis showed spherical particles of 20-80 nm for both OVA-pNIPAm and HPV-pNIPAm SAPEs (Figure 2) but no particles for HPV-pDMAm conjugate. The mean hydrodynamic diameters of all nanoparticle formulations, determined by TEM, were smaller than those determined by DLS. In a nonmonodisperse particle suspension, the mean hydrodynamic diameter of the particles might be overestimated by DLS measurement because of the presence of large particles or small aggregates. ${ }^{52,53}$ TEM analysis of SAPE nanostructures demonstrates that the majority of the particles are in a range of 20-50 nm. However, there are a few larger particles of 200$500 \mathrm{~nm}$, which affect the actual average particle size of SAPE nanostructures as measured by DLS. Zeta potential analysis of the peptide-pNIPAm nanoparticles showed a negative zeta potential for both nanoparticles at $\mathrm{pH} 7.4$ (Table 4), which indicates the presence of negatively charged OVA or HPV peptide at the surface of the nanoparticles at $\mathrm{pH}$ 7.4. From all these results, it can be concluded that these amphiphilic peptide polymer conjugates mainly form micelles. The CAC of OVApNIPAm and HPV-pNIPAm SAPEs was $\sim 0.02 \mathrm{mg} / \mathrm{mL}$, comparable to those of other amphiphilic pNIPAM block copolymers. $^{54}$ Preparation of the peptide-pNIPAm nanoparticles was relatively easy because of the hydrophilicity of pNIPAm at ambient temperature (below the LCST of pNIPAm, $33{ }^{\circ} \mathrm{C}$ ), which allows dissolution of the peptidepNIPAm conjugates in an aqueous solution and at room temperature. Next, rapid heating of this solution resulted in small and relatively uniform nanoparticles with a narrow size distribution due to dehydration and self-assembling of the pNIPAm part of the conjugate.

3.4. In Vivo Antigen Cross-Presentation. To assess the $T$ cell activation capacity of the SAPEs in vivo, OVA-specific $\mathrm{CD}^{+}$ $\mathrm{T}$ cells (OT-I) were injected into C57BL/6 mice 1 day before administration of OVA containing SAPEs. In this way, the precursor frequency of OVA-specific $\mathrm{T}$ cells was artificially elevated to high levels, thereby facilitating the read-out of in vivo antigen processing and presentation and enabling the detection of subtle differences between vaccine formulations in terms of (cross-)presentation of the OVA antigens. The degree of OT-I T cells expansion as a consequence of in vivo (cross)presentation of the OVA antigens at various time points after vaccination is shown in Figure 3. High numbers of OT-I cells were observed in the blood samples peaking at day 5 after vaccination with both SAPE vaccines (OVA-SA and pNIPAmOVA) adjuvanted with $\mathrm{CpG}$, which proved stronger to the administration of the $\mathrm{OVA}_{250-264}$ peptide with $\mathrm{CpG}$ (Figure 3) $(p<0.05$ for pNIPAm-OVA). The strong expansion of OT-I cells indicated the capacity of these designed vaccines for crosspresentation, which is necessary for effective induction of cellular immunity. ${ }^{55}$ These results clearly show that SAPE 
a)

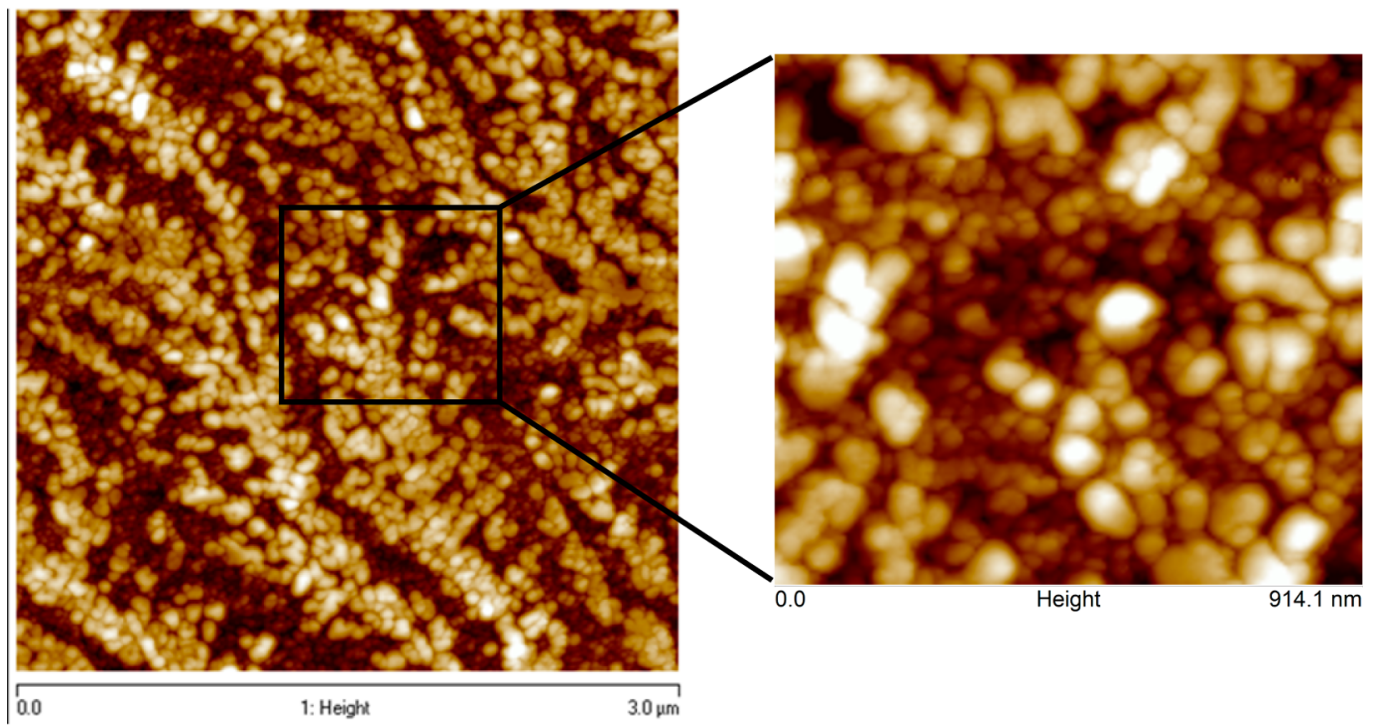

b)

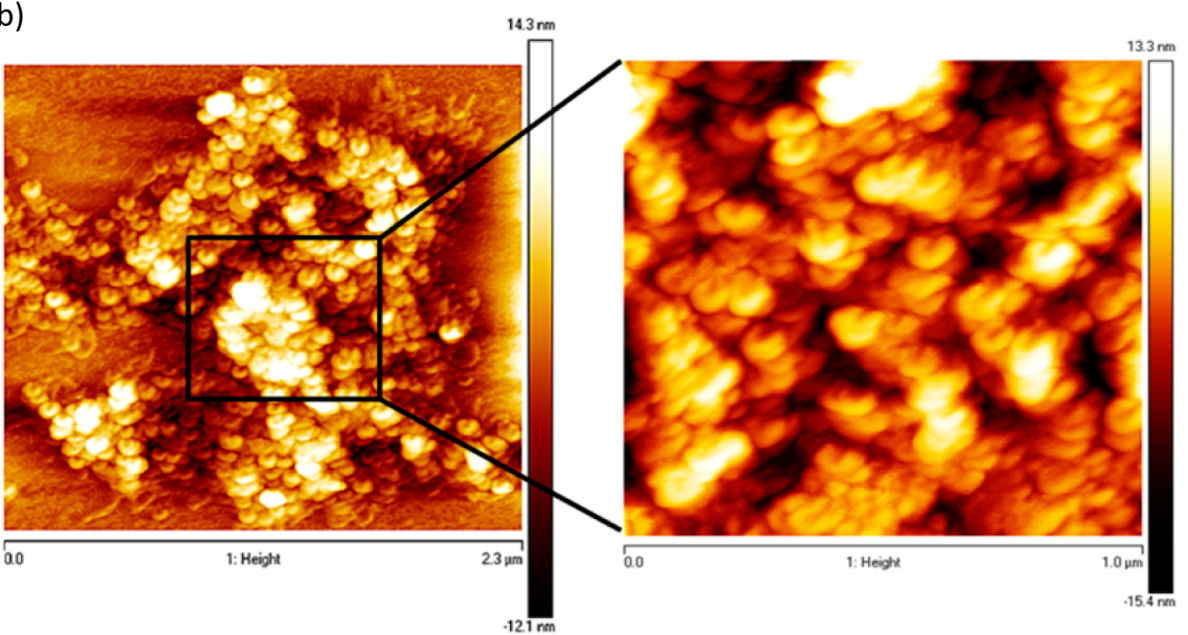

Figure 1. AFM images of (a) OVA-SA and (b) HPV-SA peptides self-assemblies immobilized on poly-L-lysine coated mica.

a)

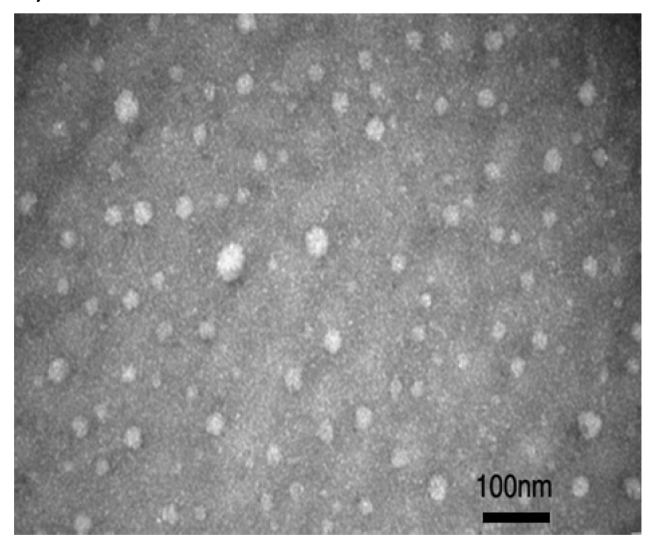

b)

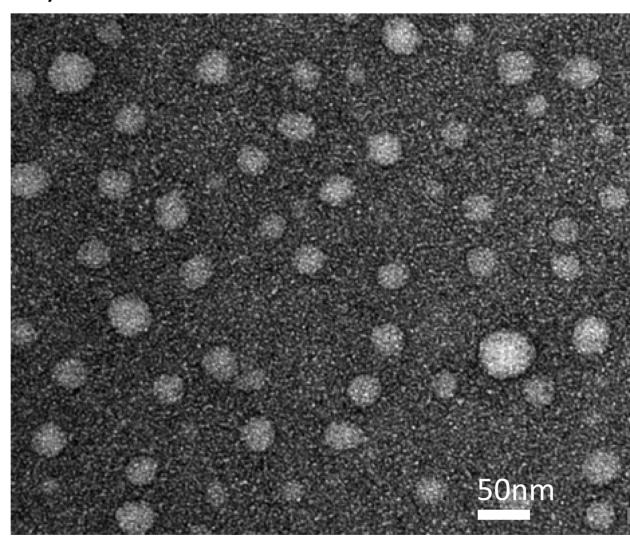

Figure 2. TEM pictures of nanoparticles composed of (a) HPV-pNIPAm and (b) OVA-pNIPAm SAPEs.

formulations adjuvanted with $\mathrm{CpG}$ are efficiently processed in vivo leading to $\mathrm{T}$ cell activation.

3.5. Endogenous Specific CD8 ${ }^{+}$T Cell Activation. The development of strong functional $\mathrm{CD}^{+} \mathrm{T}$ cells is a necessity for robust antitumor immunity. As the HPV SAPEs were further evaluated in vivo for antitumor efficacy, the immunostimulatory potential of the HPV vaccines were investigated for induction of an endogenous $\mathrm{T}$ cell response by s.c. injection of formulated SAPEs in a prime-boost regimen into naive C57BL/6 mice (Table 2). Ten days after prime 


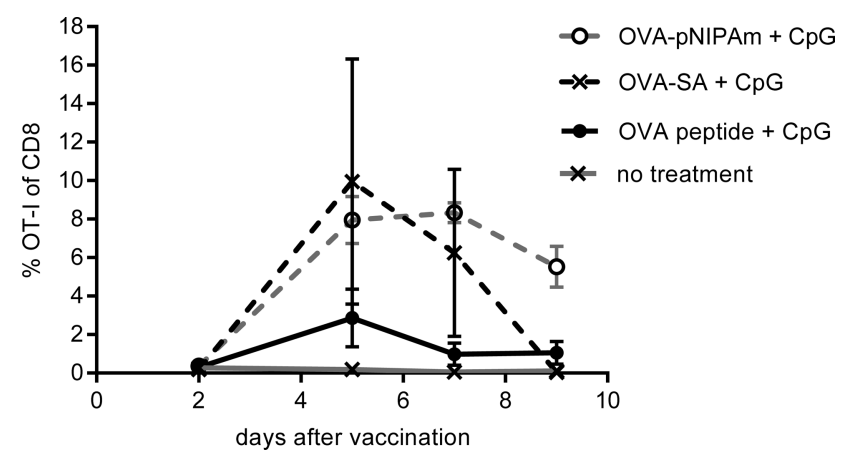

Figure 3. In vivo (cross)-presentation of OVA antigen to OVA-specific $\mathrm{CD} 8^{+}$(OT-I) $\mathrm{T}$ cells. The percentage of OT-I cells relative to the total number of $\mathrm{CD}^{+} \mathrm{T}$ cells in PMBCs of the mice vaccinated with $200 \mu \mathrm{L}$ of indicated peptide formulations (equal to $40 \mathrm{nmol}$ of OVA peptide/ injection) on days $2,5,7$, and 9 postimmunization. $N=5$ mice per group, representative of two experiments. The percentage of OT-I cells on day 5 postimmunization in mice treated with OVA-SA + CpG and OVA-pNIPAm + CpG vaccines is compared to that of soluble OVA peptide $+\mathrm{CpG}$. Statistical significance of the compared groups is calculated by student's $t$ test. $N=5$ mice per group, and data are presented as mean $\pm \mathrm{SE}$.

injection and 5 and 7 days after the booster, the induction of specific HPV CD8 ${ }^{+} \mathrm{T}$ cells in the collected blood samples was analyzed using tetramer staining.

For both adjuvanted SAPEs (HPV-SA and HPV-pNIPAm), as shown in Figure 4, the nanoassemblies were able to induce significantly higher $\mathrm{HPV}$-specific $\mathrm{CD}^{+} \mathrm{T}$ cell response in mice after booster vaccination, as compared to the control groups ( $p$ $<0.001)$. The response increased from day 5 to 7 after booster immunization $(p<0.001)$. However, after prime immunization, the mice showed weak immune responses. Thus, for such peptide vaccines, not only an adjuvant is necessary to induce a strong immune response but also a booster vaccination is important to induce strong immunity and antigen-specific memory $\mathrm{T}$ cells. ${ }^{42}$

In general, therapeutic cancer vaccines aim to raise the number of antigen-specific $\mathrm{CD}^{+}$cytotoxic $\mathrm{T}$ lymphocyte cells. ${ }^{56-58}$ Our experiments show efficient endogenous $\mathrm{CD}^{+} \mathrm{T}$ cell activation (HPV vaccines) indicating that these designed vaccines enable effective cross-presentation, which is obligatory for induction of cellular immunity. ${ }^{59}$ Our results also point out that the adjuvant and particulate system have a complementary effect to induce efficient immune responses, in agreement with other studies. ${ }^{60}$ It has been reported that $\mathrm{CpG}$ enhanced antigen cross-presentation and improved $\mathrm{CD}^{+} \mathrm{T}$ cell responses. ${ }^{61,62}$ The effect of ODNs containing unmethylated cytosine-guanine ( $\mathrm{CpG}$ ) motifs as toll-like receptor 9 (TLR-9) agonist on cellular immunity has been associated with its ability to induce and expand the number of activated DCs. In addition, it can elevate the expansion of antigen-stimulated $\mathrm{T}$ cells by inhibition of activation-induced cell death. ${ }^{63,64}$ Therefore, codelivery of efficient adjuvants such as toll-like receptor ligands with the SAPEs can improve the efficiency of such formulations. ${ }^{65,66}$ Interestingly, several peptide-based toll-like receptor ligands exist (such as RS01, Gln-Glu-Ile-Asn-Ser-SerTyr; RS09, Ala-Pro-Pro-His-Ala-Leu-Ser) that can be exploited for incorporation into SAPEs to improve CTL responses. ${ }^{67}$ Codelivery of antigen and adjuvant does not only result in proper DC activation and antigen presentation, but it also significantly lowers systemic toxicity due to reduced systemic exposure. $^{6,69}$
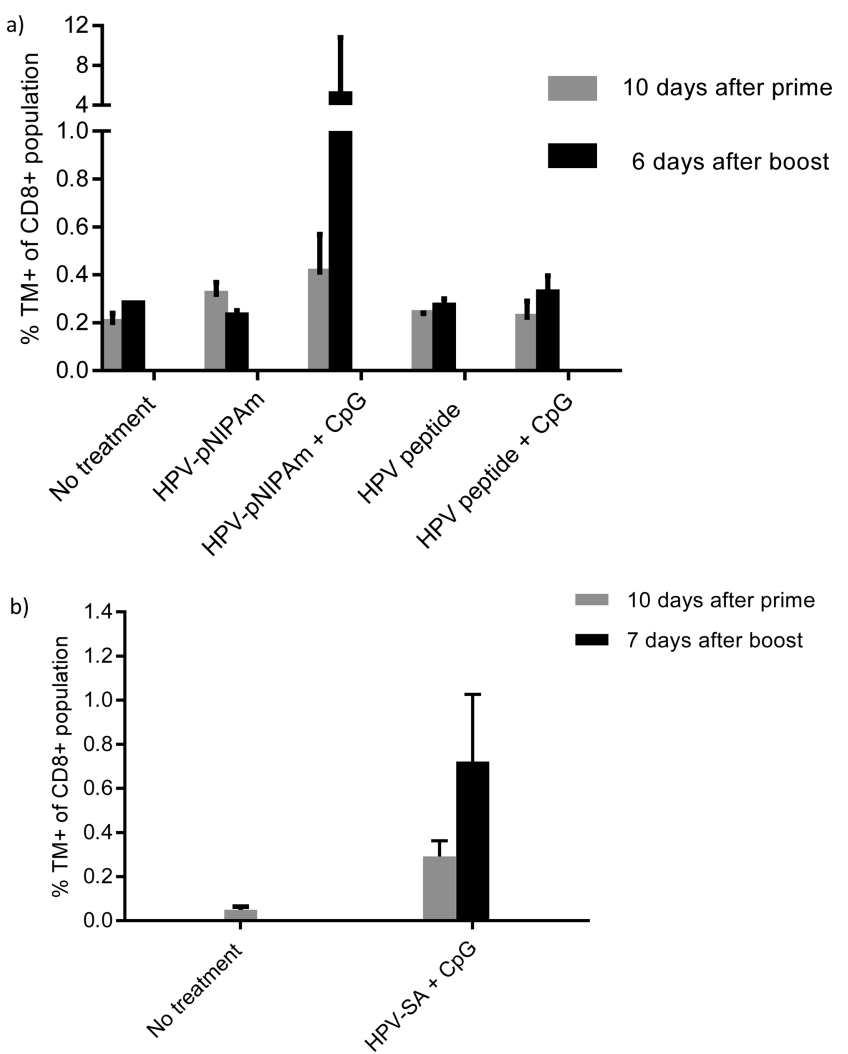

Figure 4. Percentage of endogenous HPV $16 \mathrm{E} 7_{49-57^{-}}$-specific $\mathrm{CD} 8^{+} \mathrm{T}$ cells in peripheral blood of mice vaccinated with indicated formulations (equal to $60 \mathrm{nmol}$ of HPV peptide per injection) 10 days after prime vaccination and 6 or 7 days after booster vaccination. HPV-SA + CpG was tested in a different experiment thus presented separately because of different background (untreated mice) in FACS analysis. HPV-specific CD8+T cell expansion after booster vaccination in mice treated with HPV-SA + CpG and HPV-pNIPAm + CpG vaccines is compared to untreated mice and/or soluble HPV peptide + CpG. Statistical significance of the compared groups is calculated by student's $t$ test. $N=5$ mice per group, and data are presented as mean \pm SE.

3.6. Tumor Control in Mice Treated with HPV Vaccines. To investigate the potential antitumor efficacy of HPV SAPE vaccines in a mouse model of HPV-related cancer, naïve mice were s.c. inoculated with TC-1 tumor cells expressing HPV16 oncogenes E6 and E7. Seven days after tumor inoculation (when the tumors were palpable), the treatment group received HPV SAPE vaccines adjuvanted with $\mathrm{CpG}$ in a prime-boost regimen. In addition, one group of mice was vaccinated with soluble HPV16 E7 ${ }_{43-57}$ peptide, without a self-assembling domain, $+\mathrm{CpG}$. As negative controls, one group did not receive any formulation, and one group was treated with HPV-pDMAm + CpG, a similar structure as HPVpNIPAm, without SAPE forming capacities. Tumor size was monitored over time, and the proportions of mice with a tumor size not exceeding the humane end point (tumor size of 2000 $\mathrm{mm}^{3}$ ) are presented in a Kaplan-Meier plot (Figure 5). Both HPV SAPE vaccines adjuvanted with CpG strongly delayed the tumor growth and significantly prolonged the overall survival of mice compared with untreated mice $(p<0.0005$ for HPVpNIPAm + CpG and $p<0.05$ for HPV-SA + CpG). Importantly, the HPV-pDMAm vaccine did not delay tumor outgrowth, indicating that self-assembly into nanostructures is crucial for efficient vaccine function, and merely elongating the 


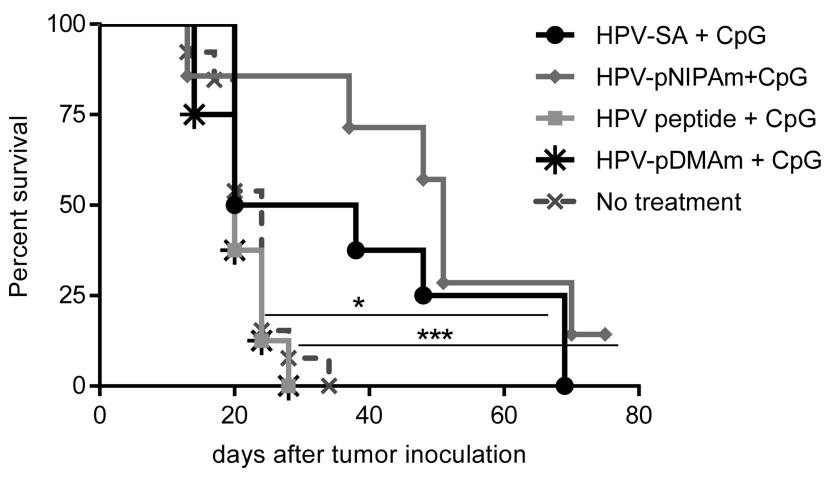

Figure 5. Survival of mice per group presented in Kaplan-Meier plot. Seven days after TC-1 tumor inoculation in wild-type C57BL/6 mice, and when tumors were palpable, mice were either left untreated or were s.c. vaccinated in the opposite flank with the indicated formulations (equal to $60 \mathrm{nmol}$ of HPV peptide per injection) followed by a boost injection 14 days after the prime dose. Statistical differences between the groups were calculated using a log-rank (Mantel-Cox) test. The survival of mice vaccinated with SAPE vaccines (HPV-SA and HPV-pNIPAm) with CpG was significantly longer compared to the no treatment group $(p<0.0005$ for HPVpNIPAm $+\mathrm{CpG}$ and $p<0.05$ for HPV-SA $+\mathrm{CpG})$. However, there was no significant difference in survival between mice vaccinated with either HPV peptide + CpG or HPV-pDMAm + CpG and untreated mice. Numbers in the legends represent median survival in days. ${ }^{*} p<$ $0.05, * * * p<0.001 . N=12$ mice per group, pooled results from two independent experiments.

peptide by attaching a long polymer chain did not enhance $\mathrm{T}$ cell activating properties. ${ }^{70}$ Moreover, development of HPVassociated tumors was not delayed by injection of only HPV16 E7 ${ }_{43-57}$ peptide $+\mathrm{CpG}$, emphasizing the need for nanoparticle formation of the peptide vaccine for efficient $\mathrm{T}$ cell priming, delaying tumor growth. These results are strongly indicative that the expansion of antigen-specific $\mathrm{T}$ cells is associated with the particulate form of peptide vaccines, while the soluble form of peptide vaccine is not effective at all.

Based on these results, it can be concluded that the soluble form of the peptide vaccine even with a strong adjuvant is not effective. However, in the form of a particular structure, it is efficiently processed and presented by DCs to activate effector $\mathrm{T}$ cells that delay the tumor growth.

It has been shown that peptide vaccines offer a promising approach to raising specific humoral or cellular immune responses against cancer cells. ${ }^{71}$ Various studies proposed to deliver peptide vaccines in a particulate form, which favors innate immune recognition and activation. ${ }^{72,73}$ Only a few studies explored peptide self-assembly as a means to present peptide epitopes in a particulate form to the immune system. For example, Collier and co-workers produced a nanofiber vaccine by incorporating a fiberizing self-assembling peptide into the structure of a peptide antigen. ${ }^{74}$ They showed that the self-assembling peptide epitope triggered the formation of highlevels of IgG1, IgG2a, and IgG3 antibodies against the attached antigen epitope. ${ }^{74}$ Most other studies used long stretches of amino acids to drive peptide self-assembly, which impedes solid phase peptide synthesis. ${ }^{75-78}$ In addition, it also increases the risk of immunogenicity against the carrier part. ${ }^{79}$ In this study, we demonstrated that by attaching an eight amino acid peptide sequence or a thermosensitive polymer tail to antigenic peptide epitopes with different length and composition, discrete nanostructures could be generated in a reproducible fashion.
This strategy can overcome some shortages of other particulate systems. Besides the ease of production and well-defined formulation, several studies indicated a correlation between epitope density and immune responses. ${ }^{80-82}$ In the designed SAPEs, the generated particles comprise a high density of antigenic epitopes displayed on the surface of nanoparticles, while in several studied polymeric nanoparticles the reported peptide loading was on the average $<5 \%$. ${ }^{83,84}$

Our in vivo results have shown that relatively short HPV peptides in particulate forms are able to significantly delay the tumor growth but did not cause complete tumor regression, and this is in agreement with previous studies. ${ }^{35,45}$ In a study, we evaluated the antitumor efficacy of a synthetic long peptide (SLP) covering HPV peptide encapsulated in polymeric nanoparticles (NPs) in a therapeutic tumor model. ${ }^{45}$ Similar to the results described here we showed that the peptide vaccine in the particulate form without adjuvant (Poly I:C) did not significantly delay tumor growth or prolong the survival of mice in comparison with untreated mice. Interestingly, peptideloaded nanoparticles with poly I:C (encapsulated or soluble) significantly prolonged the survival of mice compared to the untreated group. Although there are differences between the two studies in the experimental settings, such as the nature of the particulate carrier, type, and dosage of the adjuvants and length of HPV peptide vaccines, similar results in antitumor efficacy for the adjuvanted particulate systems in both studies were observed. These findings support our hypothesis that by simply extending the peptide epitopes with a self-assembling segment, a particulate antigen-delivery system can be established without laborious processing and formulation steps.

\section{CONCLUSION}

We conclude that nanoparticle formation based on the introduced self-assembling materials for peptide vaccines can be an attractive approach and simple alternative for other particulate systems. The extension of minimal epitopes by a self-assembling segment can efficiently augment the induction of a desired immune response: first, by risk reduction of $\mathrm{T}$ cell anergy since the segments have to be processed by DCs to release the minimal epitopes; second, by enhancing cellular uptake of particulate vaccines and antigen-specific $\mathrm{T}$ cell response. The described approach exploits the advantages of self-assembling peptide epitopes to improve tumor-specific $\mathrm{T}$ cell response for cancer treatment.

In conclusion, this study demonstrates that self-assembling peptide-peptide and peptide-polymer conjugates are attractive systems for molecularly well-defined vaccines.

\section{ASSOCIATED CONTENT}

\section{Supporting Information}

The Supporting Information is available free of charge on the ACS Publications website at DOI: 10.1021/acs.molpharmaceut.6b01003.

Circular dichroism of the self-assembling peptide epitopes in phosphate buffer; gating strategy; tumor volume in tumor bearing mice (PDF)

\section{AUTHOR INFORMATION}

\section{Corresponding Authors}

*E-mail: w.e.hennink@uu.nl. Phone: +31 302536964.

*E-mail: m.amidi@uu.nl. Phone: +31 626690621. 


\section{ORCID}

Wim E. Hennink: 0000-0002-5750-714X

\section{Author Contributions}

"The authors contributed equally to this work.

\section{Notes}

The authors declare no competing financial interest.

\section{ACKNOWLEDGMENTS}

This work was supported by The Netherlands Organization for Scientific Research (NWO), division of the Technology Foundation (STW); Project number: 11209.

\section{REFERENCES}

(1) Arens, R.; van Hall, T.; van der Burg, S. H.; Ossendorp, F.; Melief, C. J. M. Prospects of Combinatorial Synthetic Peptide VaccineBased Immunotherapy against Cancer. Semin. Immunol. 2013, 25 (2), 182-190.

(2) Couzin-Frankel, J. Cancer Immunotherapy. Science 2013, 342 (6165), 1432-1433.

(3) Melief, C. J. M.; van Hall, T.; Arens, R.; Ossendorp, F.; van der Burg, S. H. Therapeutic Cancer Vaccines. J. Clin. Invest. 2015, 125 (9), 3401-3412.

(4) van der Burg, S. H.; Arens, R.; Ossendorp, F.; van Hall, T.; Melief, C. J. M. Vaccines for Established Cancer: Overcoming the Challenges Posed by Immune Evasion. Nat. Rev. Cancer 2016, 16 (4), 219-233.

(5) Itoh, K.; Yamada, A.; Mine, T.; Noguchi, M. Recent Advances in Cancer Vaccines: An Overview. Jpn. J. Clin. Oncol. 2008, 39, 73-80.

(6) Cuppens, K.; Vansteenkiste, J. Vaccination Therapy for NonSmall-Cell Lung Cancer. Curr. Opin. Oncol. 2014, 26 (2), 165-170.

(7) Melero, I.; Gaudernack, G.; Gerritsen, W.; Huber, C.; Parmiani, G.; Scholl, S.; Thatcher, N.; Wagstaff, J.; Zielinski, C.; Faulkner, I.; Mellstedt, H. Therapeutic Vaccines for Cancer: An Overview of Clinical Trials. Nat. Rev. Clin. Oncol. 2014, 11 (9), 509-524.

(8) Yang, J.; Zhang, Q.; Li, K.; Yin, H.; Zheng, J.-N. Composite Peptide-Based Vaccines for Cancer Immunotherapy (Review). Int. J. Mol. Med. 2015, 35 (1), 17-23.

(9) Welters, M. J. P.; Bijker, M. S.; van den Eeden, S. J. F.; Franken, K. L. M. C.; Melief, C. J. M.; Offringa, R.; van der Burg, S. H. Multiple CD4 and CD8 T-Cell Activation Parameters Predict Vaccine Efficacy in Vivo Mediated by Individual DC-Activating Agonists. Vaccine 2007, 25 (8), 1379-1389.

(10) Bijker, M. S.; Van Den Eeden, S. J. F.; Franken, K. L.; Melief, C. J. M.; Offringa, R.; Van Der Burg, S. H. CD8+ CTL Priming by Exact Peptide Epitopes in Incomplete Freund's Adjuvant Induces a Vanishing CTL Response, Whereas Long Peptides Induce Sustained CTL Reactivity. J. Immunol. 2007, 179 (8), 5033-5040.

(11) Bijker, M. S.; Melief, C. J. M.; Offringa, R; van der Burg, S. H. Design and Development of Synthetic Peptide Vaccines: Past, Present and Future. Expert Rev. Vaccines 2007, 6 (4), 591-603.

(12) Weijzen, S.; Meredith, S. C.; Velders, M. P.; Elmishad, A. G.; Schreiber, H.; Kast, W. M. Pharmacokinetic Differences between a T Cell-Tolerizing and a T Cell-Activating Peptide. J. Immunol. 2001, 166 (12), 7151-7157.

(13) Mehta, N. K.; Moynihan, K. D.; Irvine, D. J. Engineering New Approaches to Cancer Vaccines. Cancer Immunol. Res. 2015, 3 (8), 836-843.

(14) Toes, R. E. M.; Offringa, R.; Blom, R. J. J.; Melief, C. J. M.; Kast, W. M. Peptide Vaccination Can Lead to Enhanced Tumor Growth through Specific T-Cell Tolerance Induction. Proc. Natl. Acad. Sci. U. S. A. 1996, 93 (15), 7855-7860.

(15) Aichele, P.; Brduscha-Riem, K.; Zinkernagel, R. M.; Hengartner, H.; Pircher, H. T Cell Priming versus T Cell Tolerance Induced by Synthetic Peptides. J. Exp. Med. 1995, 182 (1), 261-266.

(16) Melief, C. J. M.; Van Der Burg, S. H. Immunotherapy of Established (pre)malignant Disease by Synthetic Long Peptide Vaccines. Nat. Rev. Cancer 2008, 8 (5), 351-360.
(17) Bijker, M. S.; Melief, C. J. M.; Offringa, R; van der Burg, S. H. Design and Development of Synthetic Peptide Vaccines: Past, Present and Future. Expert Rev. Vaccines 2007, 6 (4), 591-603.

(18) Vogel, F. R. Improving Vaccine Performance with Adjuvants. Clin. Infect. Dis. 2000, 30, S266-S270.

(19) Rosalia, R. A.; Cruz, L. J.; van Duikeren, S.; Tromp, A. T.; Silva, A. L.; Jiskoot, W.; de Gruijl, T.; Löwik, C.; Oostendorp, J.; van der Burg, S. H.; Ossendorp, F. CD40-Targeted Dendritic Cell Delivery of PLGA-Nanoparticle Vaccines Induce Potent Anti-Tumor Responses. Biomaterials 2015, 40, 88-97.

(20) Dimier-Poisson, I.; Carpentier, R.; N’Guyen, T. T. L.; Dahmani, F.; Ducournau, C.; Betbeder, D. Porous Nanoparticles as Delivery System of Complex Antigens for an Effective Vaccine against Acute and Chronic Toxoplasma Gondii Infection. Biomaterials 2015, 50 (1), 164-175.

(21) Chen, W.; Huang, L. Induction of Cytotoxic T-Lymphocytes and Antitumor Activity by a Liposomal Lipopeptide Vaccine. Mol. Pharmaceutics 2008, 5 (3), 464-471.

(22) Thomas, C.; Rawat, A.; Hope-Weeks, L.; Ahsan, F. Aerosolized PLA and PLGA Nanoparticles Enhance Humoral, Mucosal and Cytokine Responses to Hepatitis B Vaccine. Mol. Pharmaceutics 2011, 8 (2), 405-415.

(23) Irvine, D. J.; Hanson, M. C.; Rakhra, K.; Tokatlian, T. Synthetic Nanoparticles for Vaccines and Immunotherapy. Chem. Rev. 2015, 115 (19), 11109-11146.

(24) De Geest, B. G.; Willart, M. A.; Hammad, H.; Lambrecht, B. N.; Pollard, C.; Bogaert, P.; De Filette, M.; Saelens, X.; Vervaet, C.; Remon, J. P.; Grooten, J.; De Koker, S. Polymeric Multilayer CapsuleMediated Vaccination Induces Protective Immunity Against Cancer and Viral Infection. ACS Nano 2012, 6 (3), 2136-2149.

(25) Rad-Malekshahi, M.; Lempsink, L.; Amidi, M.; Hennink, W. E.; Mastrobattista, E. Biomedical Applications of Self-Assembling Peptides. Bioconjugate Chem. 2016, 27 (1), 3-18.

(26) Rad-Malekshahi, M.; Flement, M.; Hennink, W. E.; Mastrobattista, E. Optimization of the Recombinant Production and Purification of a Self-Assembling Peptide in Escherichia Coli. Microb. Cell Fact. 2014, 13, 987.

(27) Merrifield, R. B. Solid Phase Peptide Synthesis. I. The Synthesis of a Tetrapeptide. J. Am. Chem. Soc. 1963, 85 (14), 2149-2154.

(28) van Hell, A. J.; Costa, C. I. C. A.; Flesch, F. M.; Sutter, M.; Jiskoot, W.; Crommelin, D. J. A.; Hennink, W. E.; Mastrobattista, E. Self-Assembly of Recombinant Amphiphilic Oligopeptides into Vesicles. Biomacromolecules 2007, 8, 2753-2761.

(29) Rad-Malekshahi, M.; Visscher, K. M.; Rodrigues, J. P. G. L. M.; de Vries, R.; Hennink, W. E.; Baldus, M.; Bonvin, A. M. J. J.; Mastrobattista, E.; Weingarth, M. The Supramolecular Organization of a Peptide-Based Nanocarrier at High Molecular Detail. J. Am. Chem. Soc. 2015, 137, 7775-7784.

(30) van Hell, A. J.; Costa, C.; Flesch, F. M.; Sutter, M.; Jiskoot, W.; Crommelin, D. J. A.; Hennink, W. E.; Mastrobattista, E. Self-Assembly of Recombinant Amphiphilic Oligopeptides into Vesicles. Biomacromolecules 2007, 8, 2753-2761.

(31) Langer, R.; Vacanti, J. Advances in Tissue Engineering. J. Pediatr. Surg. 2016, 51 (1), 8-12.

(32) Hoffman, A. S. Stimuli-Responsive Polymers: Biomedical Applications and Challenges for Clinical Translation. Adv. Drug Delivery Rev. 2013, 65 (1), 10-16.

(33) Cheng, R.; Feng, F.; Meng, F.; Deng, C.; Feijen, J.; Zhong, Z. Glutathione-Responsive Nano-Vehicles as a Promising Platform for Targeted Intracellular Drug and Gene Delivery. J. Controlled Release 2011, 152 (1), 2-12.

(34) de Graaf, A. J.; Azevedo Próspero dos Santos, I. I.; Pieters, E. H. E.; Rijkers, D. T. S.; van Nostrum, C. F.; Vermonden, T.; Kok, R. J.; Hennink, W. E.; Mastrobattista, E. A Micelle-Shedding Thermosensitive Hydrogel as Sustained Release Formulation. J. Controlled Release 2012, 162 (3), 582-590.

(35) Zwaveling, S.; Mota, S. C. F.; Nouta, J.; Johnson, M.; Lipford, G. B.; Offringa, R.; Van der Burg, S. H.; Melief, C. J. M. Established Human Papillomavirus Type 16-Expressing Tumors Are Effectively 
Eradicated Following Vaccination with Long Peptides. J. Immunol. 2002, 169 (1), 350-358.

(36) Kaiser, E.; Colescott, R. L.; Bossinger, C. D.; Cook, P. I. Color Test for Detection of Free Terminal Amino Groups in the Solid-Phase Synthesis of Peptides. Anal. Biochem. 1970, 34 (2), 595-598.

(37) De Graaf, A. J.; Boere, K. W. M.; Kemmink, J.; Fokkink, R. G.; Van Nostrum, C. F.; Rijkers, D. T. S.; Van Der Gucht, J.; Wienk, H.; Baldus, M.; Mastrobattista, E.; Vermonden, T.; Hennink, W. E. Looped Structure of Flowerlike Micelles Revealed by 1H NMR Relaxometry and Light Scattering. Langmuir 2011, 27 (16), 98439848.

(38) Rijcken, C. J.; Snel, C. J.; Schiffelers, R. M.; van Nostrum, C. F.; Hennink, W. E. Hydrolysable Core-Crosslinked Thermosensitive Polymeric Micelles: Synthesis, Characterisation and in Vivo Studies. Biomaterials 2007, 28 (36), 5581-5593.

(39) Neradovic, D.; Soga, O.; Van Nostrum, C. F.; Hennink, W. E. The Effect of the Processing and Formulation Parameters on the Size of Nanoparticles Based on Block Copolymers of Poly(ethylene Glycol) and poly(N-Isopropylacrylamide) with and without Hydrolytically Sensitive Groups. Biomaterials 2004, 25 (12), 2409-2418.

(40) Zhang, A.; Zhang, Z.; Shi, F.; Ding, J.; Xiao, C.; Zhuang, X.; He, C.; Chen, L.; Chen, X. Disulfide Crosslinked PEGylated Starch Micelles as Efficient Intracellular Drug Delivery Platforms. Soft Matter 2013, 9 (7), 2224-2233.

(41) Lin, K. Y.; Guarnieri, F. G.; Staveley-O’Carroll, K. F.; Levitsky, H. I.; August, J. T.; Pardoll, D. M.; Wu, T. C. Treatment of Established Tumors with a Novel Vaccine That Enhances Major Histocompatibility Class II Presentation of Tumor Antigen. Cancer Res. 1996, 56 (1), 21-26.

(42) Van Duikeren, S.; Fransen, M. F.; Redeker, A.; Wieles, B.; Platenburg, G.; Krebber, W.-J.; Ossendorp, F.; Melief, C. J. M.; Arens, R. Vaccine-Induced Effector-Memory CD8+ T Cell Responses Predict Therapeutic Efficacy against Tumors. J. Immunol. 2012, 189 (7), 3397-3403.

(43) Li, M.; Zhang, Y.; Liu, Z.; Bharadwaj, U.; Wang, H.; Wang, X.; Zhang, S.; Liuzzi, J. P.; Chang, S.-M.; Cousins, R. J.; Fisher, W. E.; Brunicardi, F. C.; Logsdon, C. D.; Chen, C.; Yao, Q. Aberrant Expression of Zinc Transporter ZIP4 (SLC39A4) Significantly Contributes to Human Pancreatic Cancer Pathogenesis and Progression. Proc. Natl. Acad. Sci. U. S. A. 2007, 104 (47), 1863618641.

(44) Welters, M. J. P.; Bijker, M. S.; van den Eeden, S. J. F.; Franken, K. L. M. C.; Melief, C. J. M.; Offringa, R.; van der Burg, S. H. Multiple CD4 and CD8 T-Cell Activation Parameters Predict Vaccine Efficacy in Vivo Mediated by Individual DC-Activating Agonists. Vaccine 2007, 25 (8), 1379-1389.

(45) Rahimian, S.; Fransen, M. F.; Kleinovink, J. W.; Christensen, J. R.; Amidi, M.; Hennink, W. E.; Ossendorp, F. Polymeric Nanoparticles for Co-Delivery of Synthetic Long Peptide Antigen and Poly IC as Therapeutic Cancer Vaccine Formulation. J. Controlled Release 2015, 203, 16-22.

(46) Sumerlin, B. S. Proteins as Initiators of Controlled Radical Polymerization: Grafting-from via ATRP and RAFT. ACS Macro Lett. 2012, 1 (1), 141-145.

(47) Averick, S.; Mehl, R. A.; Das, S. R.; Matyjaszewski, K. WellDefined Biohybrids Using Reversible-Deactivation Radical Polymerization Procedures. J. Controlled Release 2015, 205, 45-57.

(48) Schild, H. G. Poly(N-Isopropylacrylamide): Experiment, Theory and Application. Prog. Polym. Sci. 1992, 17 (2), 163-249.

(49) Topp, M. D. C.; Dijkstra, P. J.; Talsma, H.; Feijen, J. Thermosensitive Micelle-Forming Block Copolymers of Poly(ethylene Glycol) and Poly(N-Isopropylacrylamide). Macromolecules 1997, 30 (26), 8518-8520.

(50) Protein Calculator v3.4. http://protcalc.sourceforge.net/ (accessed Nov 2, 2016).

(51) Rudra, J. S.; Sun, T.; Bird, K. C.; Daniels, M. D.; Gasiorowski, J. Z.; Chong, A. S.; Collier, J. H. Modulating Adaptive Immune Responses to Peptide Self-Assemblies. ACS Nano 2012, 6 (2), 15571564.
(52) Bootz, A.; Vogel, V.; Schubert, D.; Kreuter, J. Comparison of Scanning Electron Microscopy, Dynamic Light Scattering and Analytical Ultracentrifugation for the Sizing of Poly(butyl Cyanoacrylate) Nanoparticles. Eur. J. Pharm. Biopharm. 2004, 57 (2), 369-375.

(53) Filipe, V.; Hawe, A.; Jiskoot, W. Critical Evaluation of Nanoparticle Tracking Analysis (NTA) by NanoSight for the Measurement of Nanoparticles and Protein Aggregates. Pharm. Res. 2010, 27 (5), 796-810.

(54) Klaikherd, A.; Nagamani, C.; Thayumanavan, S. Multi-Stimuli Sensitive Amphiphilic Block Copolymer Assemblies. J. Am. Chem. Soc. 2009, 131 (13), 4830-4838.

(55) Hjálmsdóttir, Á.; Bühler, C.; Vonwil, V.; Roveri, M.; Håkerud, M.; Wäckerle-Men, Y.; Gander, B.; Johansen, P. Cytosolic Delivery of Liposomal Vaccines by Means of the Concomitant Photosensitization of Phagosomes. Mol. Pharmaceutics 2016, 13 (2), 320-329.

(56) Kapadia, C. H.; Tian, S.; Perry, J. L.; Luft, J. C.; DeSimone, J. M. Reduction Sensitive PEG Hydrogels for Codelivery of Antigen and Adjuvant To Induce Potent CTLs. Mol. Pharmaceutics 2016, 13 (10), 3381-3394.

(57) Rosenberg, S. A.; Yang, J. C.; Restifo, N. P. Cancer Immunotherapy: Moving beyond Current Vaccines. Nat. Med. 2004, 10 (9), 909-915.

(58) Wong, K. K.; Li, W. A.; Mooney, D. J.; Dranoff, G. Advances in Therapeutic Cancer Vaccines. In Tumor Immunology; Academic Press: 2016; Vol. 130, Chapter Five, pp 191-249.

(59) Ackerman, A. L.; Cresswell, P. Cellular Mechanisms Governing Cross-Presentation of Exogenous Antigens. Nat. Immunol. 2004, 5 (7), $678-684$.

(60) Ilyinskii, P. O.; Roy, C. J.; O’Neil, C. P.; Browning, E. A.; Pittet, L. A.; Altreuter, D. H.; Alexis, F.; Tonti, E.; Shi, J.; Basto, P. A.; Iannacone, M.; Radovic-Moreno, A. F.; Langer, R. S.; Farokhzad, O. C.; von Andrian, U. H.; Johnston, L. P. M.; Kishimoto, T. K. AdjuvantCarrying Synthetic Vaccine Particles Augment the Immune Response to Encapsulated Antigen and Exhibit Strong Local Immune Activation without Inducing Systemic Cytokine Release. Vaccine 2014, 32 (24), $2882-2895$

(61) Lahiri, A.; Lahiri, A.; Das, P.; Vani, J.; Shaila, M. S.; Chakravortty, D. TLR 9 Activation in Dendritic Cells Enhances Salmonella Killing and Antigen Presentation via Involvement of the Reactive Oxygen Species. PLoS One 2010, 5 (10), e13772.

(62) Najar, H. M.; Dutz, J. P. Topical CpG Enhances the Response of Murine Malignant Melanoma to Dacarbazine. J. Invest. Dermatol. 2008, 128 (9), 2204-2210.

(63) Davila, E.; Kennedy, R.; Cells, E. Generation of Antitumor Immunity by Cytotoxic T Lymphocyte Epitope Peptide Vaccination, CpG-Oligodeoxynucleotide Adjuvant, and CTLA-4 Blockade. Cancer Res. 2003, 63 (12), 3281-3288.

(64) Grossmann, M. E.; Davila, E.; Celis, E. Avoiding Tolerance against Prostatic Antigens with Subdominant Peptide Epitopes. J. Immunother. 2001, 24 (3), 237-241.

(65) Primard, C.; Poecheim, J.; Heuking, S.; Sublet, E.; Esmaeili, F.; Borchard, G. Multifunctional PLGA-Based Nanoparticles Encapsulating Simultaneously Hydrophilic Antigen and Hydrophobic Immunomodulator for Mucosal Immunization. Mol. Pharmaceutics 2013, 10 (8), 2996-3004.

(66) Sun, Z. Y.; Chen, P. G.; Liu, Y. F.; Zhang, B. D.; Wu, J. J.; Chen, Y. X.; Zhao, Y. F.; Li, Y. M. Multi-Component Self-Assembled AntiTumor Nano-Vaccines Based on MUC1 Glycopeptides. Chem. Commun. 2016, 52 (48), 7572-7575.

(67) Shanmugam, A.; Rajoria, S.; George, A. L.; Mittelman, A.; Suriano, R.; Tiwari, R. K. Synthetic Toll like Receptor-4 (TLR-4) Agonist Peptides as a Novel Class of Adjuvants. PLoS One 2012, 7 (2), e30839.

(68) Ilyinskii, P. O.; Roy, C. J.; O’Neil, C. P.; Browning, E. A.; Pittet, L. A.; Altreuter, D. H.; Alexis, F.; Tonti, E.; Shi, J.; Basto, P. A.; Iannacone, M.; Radovic-Moreno, A. F.; Langer, R. S.; Farokhzad, O. C.; von Andrian, U. H.; Johnston, L. P. M.; Kishimoto, T. K. AdjuvantCarrying Synthetic Vaccine Particles Augment the Immune Response to Encapsulated Antigen and Exhibit Strong Local Immune Activation 
without Inducing Systemic Cytokine Release. Vaccine 2014, 32 (24), 2882-2895.

(69) Silva, A. L.; Soema, P. C.; Slütter, B.; Ossendorp, F.; Jiskoot, W. PLGA Particulate Delivery Systems for Subunit Vaccines: Linking Particle Properties to Immunogenicity. Hum. Vaccines Immunother. 2016, 12 (4), 1056-1069.

(70) Shae, D.; Postma, A.; Wilson, J. T. Vaccine Delivery: Where Polymer Chemistry Meets Immunology. Ther. Delivery 2016, 7 (4), 193-196.

(71) Slingluff, C. L. The Present and Future of Peptide Vaccines for Cancer. Cancer J. 2011, 17 (5), 343-350.

(72) Storni, T.; Kündig, T. M.; Senti, G.; Johansen, P. Immunity in Response to Particulate Antigen-Delivery Systems. Adv. Drug Delivery Rev. 2005, 57 (3), 333-355.

(73) De Temmerman, M.-L.; Rejman, J.; Demeester, J.; Irvine, D. J.; Gander, B.; De Smedt, S. C. Particulate Vaccines: On the Quest for Optimal Delivery and Immune Response. Drug Discovery Today 2011, 16 (13-14), 569-582.

(74) Rudra, J. S.; Tian, Y. F.; Jung, J. P.; Collier, J. H. A SelfAssembling Peptide Acting as an Immune Adjuvant. Proc. Natl. Acad. Sci. U. S. A. 2010, 107 (2), 622-627.

(75) Miller, K. D.; Roque, R.; Clegg, C. H. Novel Anti-Nicotine Vaccine Using a Trimeric Coiled-Coil Hapten Carrier. PLoS One 2014, 9 (12), e114366.

(76) Boato, F.; Thomas, R. M.; Ghasparian, A.; Freund-Renard, A.; Moehle, K.; Robinson, J. A. Synthetic Virus-like Particles from SelfAssembling Coiled-Coil Lipopeptides and Their Use in Antigen Display to the Immune System. Angew. Chem., Int. Ed. 2007, 46 (47), 9015-9018.

(77) Kaba, S. A.; Brando, C.; Guo, Q.; Mittelholzer, C.; Raman, S.; Tropel, D.; Aebi, U.; Burkhard, P.; Lanar, D. E. A Nonadjuvanted Polypeptide Nanoparticle Vaccine Confers Long-Lasting Protection against Rodent Malaria. J. Immunol. 2009, 183 (11), 7268-7277.

(78) Al-Warhi, T. I.; Al-Hazimi, H. M. A.; El-Faham, A. Recent Development in Peptide Coupling Reagents. J. Saudi Chem. Soc. 2012, 16 (2), 97-116.

(79) Schlossman, S. F.; Yaron, A.; Ben-Efraim, S.; Sober, H. A. Immunogenicity of a Series of $\alpha$, N-DNP-L-Lysines. Biochemistry 1965, 4 (8), 1638-1645.

(80) Liu, W.; Chen, Y.-H. High Epitope Density in a Single Protein Molecule Significantly Enhances Antigenicity as Well as Immunogenecity: A Novel Strategy for Modern Vaccine Development and a Preliminary Investigation about B Cell Discrimination of Monomeric Proteins. Eur. J. Immunol. 2005, 35 (2), 505-514.

(81) Kersten, G. F. A.; Crommelin, D. J. A. Liposomes and ISCOMS as Vaccine Formulations. Biochim. Biophys. Acta, Rev. Biomembr. 1995, 1241 (2), 117-138.

(82) Reche, P. A.; Fernandez-Caldas, E.; Flower, D. R.; FridkisHareli, M.; Hoshino, Y. Peptide-Based Immunotherapeutics and Vaccines. J. Immunol. Res. 2014, 2014, 256784.

(83) Silva, A. L.; Rosalia, R. A.; Varypataki, E.; Sibuea, S.; Ossendorp, F.; Jiskoot, W. Poly-(lactic-Co-Glycolic-Acid)-Based Particulate Vaccines: Particle Uptake by Dendritic Cells Is a Key Parameter for Immune Activation. Vaccine 2015, 33 (7), 847-854.

(84) Rahimian, S.; Kleinovink, J. W.; Fransen, M. F.; Mezzanotte, L.; Gold, H.; Wisse, P.; Overkleeft, H.; Amidi, M.; Jiskoot, W.; Löwik, C. W.; Ossendorp, F.; Hennink, W. E. Near-Infrared Labeled, Ovalbumin Loaded Polymeric Nanoparticles Based on a Hydrophilic Polyester as Model Vaccine: In Vivo Tracking and Evaluation of Antigen-Specific CD8(+) T Cell Immune Response. Biomaterials 2014, 37, 469-477. 